E-ISSN : 2549-6581

DOI: 10.21776/ub.JOIM.2021.005.03.2

Artikel Hasil Penelitian

Diterima : 6 Desember 2021

Direview : 13 September 2021

Dimuat : Desember 2021 - Maret 2022

\section{OPEN ACCESS}

Journal of Issues in Midwifery

\title{
Pengaruh Stunting Terhadap Perkembangan Pada Anak Balita Usia 2-5 Tahun Di Desa Madiredo Kecamatan Pujon Kabupaten Malang
}

\author{
Meishita Wulansari $^{1 *}$, Ni Luh Putu Herli Mastuti ${ }^{2}$, Lilik Indahwati ${ }^{3}$ \\ ${ }^{\left.{ }^{*}\right)}$ Program Studi Sarjana Kebidanan, Fakultas Kedokteran, Universitas Brawijaya, E-mail: \\ meishitaws@gmail.com, Tlp: +6285234653361 \\ ${ }^{2,3}$ Program Studi Sarjana Kebidanan, Fakultas Kedokteran, Universitas Brawijaya
}

\begin{abstract}
Stunting is one of the growth problems that occurs in children due to chronic malnutrition for a long period so that they are shorter and thinner than those at their age. If the children's growth is stunted, then the children's development process that includes the development of fine motor, gross motor, language and personal-social can also be stunted. The purpose of this study was to determine the effect of stunting on the development of fine motor skills, gross motor skills, language and personal-social of children aged 2-5 years in Desa Madiredo, Kecamatan Pujon, Kabupaten Malang. The design of this study was cross sectional. Stunting nutritional status was measured by the z-score of height for age (HAZ), it was obtained <-2 Standard Deviations based on World Health Organization standards, then the $z$-scores between the median age of $W A Z<$ median age of $H A Z<$ age chronological children were compared. Meanwhile, children's development was measured using the Denver Development Screening Test II (Denver II). The subjects in this study were children aged 2-5 years in Desa Madiredo $(n=46)$ who fulfilled the inclusion criteria and were selected by purposive sampling method. The results of the study implementing the Fisher's Exact Test $(\alpha=0.05)$ indicated that stunting did not have a significant effect on fine motor development ( $p$ value $=0.233$ ) and gross motor ( $p$ value $=0.109$ ). Meanwhile, stunting had a significant effect on the language development ( $p$ value $=0.022$ ) and personal-social ( $p$ value $=0.004$ ). The conclusion of this study was that stunting affected the language and personal-social development of children aged 2-5 years. The suggestion for the community was to pay attention continuously to the growth and development of children well, because both were closely interrelated to improve the quality of human resources.
\end{abstract}

Keywords: Development, Child, Stunting

\begin{abstract}
ABSTRAK
Stunting merupakan salah satu masalah pertumbuhan yang terjadi pada anak akibat kekurangan gizi kronis dalam jangka waktu yang lama, sehingga anak berperawakan lebih pendek dan kurus dari anak seusianya. Apabila pertumbuhan anak terhambat, maka proses perkembangan anak yang meliputi perkembangan
\end{abstract}


motorik halus, motorik kasar, bahasa dan personal sosial juga dapat terhambat. Tujuan penelitian ini adalah untuk mengetahui pengaruh stunting terhadap perkembangan motorik halus, motorik kasar, bahasa dan personal sosial anak balita usia 2-5 tahun di Desa Madiredo, Kecamatan Pujon, Kabupaten Malang. Desain penelitian ini menggunakan cross sectional. Status gizi stunting diukur dengan nilai $z$-score tinggi badan dengan umur (TB/U) didapatkan <-2 Standar Deviasi berdasarkan standar World Health Organization, kemudian dibandingkan nilai $z$-score antara usia median BB/U<usia median $\mathrm{TB} / \mathrm{U}<$ usia kronologis anak. Perkembangan anak diukur menggunakan Denver Development Screening Test II (Denver II). Subjek dalam penelitian ini adalah anak balita usia 2-5 tahun di Desa Madiredo $(n=46)$ yang memenuhi kriteria inklusi dan dipilih dengan metode purposive sampling. Hasil penelitian dengan menggunakan Uji Fisher's Exact $(\alpha=0,05)$ menunjukkan bahwa stunting tidak memiliki pengaruh yang signifikan terhadap perkembangan motorik halus ( $p$ value $=0,233$ ) dan motorik kasar $(p$ value $=0,109)$. Stunting memiliki pengaruh yang signifikan terhadap perkembangan bahasa $(p$ value $=0,022)$ dan personal sosial ( $p$ value $=0,004$ ). Kesimpulan dari penelitian ini adalah stunting memengaruhi perkembangan bahasa dan personal sosial anak balita usia 2-5 tahun. Saran bagi masyarakat yaitu agar senantiasa memperhatikan pertumbuhan dan perkembangan anak dengan baik, karena keduanya saling berkaitan erat untuk meningkatkan kualitas sumber daya manusia.

Kata Kunci: Perkembangan, Anak, Stunting

‘Korespondensi: Meishita Wulansari. Surel: meishitaws@gmail.com

\section{PENDAHULUAN}

Stunting merupakan gangguan pertumbuhan dikarenakan adanya kekurangan gizi kronis dan atau penyakit infeksi kronis maupun berulang yang ditunjukkan dengan nilai z-score tinggi badan menurut usia (TB/U) $<-2$ Standar Deviasi (SD) berdasarkan standar World Health Organization $(W H O)^{(1)}$. Metode terbaru untuk penentuan anak stunting yaitu dengan cara mengetahui anak pendek dengan menggunakan TB/U <-2SD, lalu dikaji penyebabnya nutrisi atau non nutrisi. Setelah itu ditentukan usia median $\mathrm{BB} / \mathrm{U}$, usia median TB/U dan usia kronologis. Apabila didapatkan hasil usia median $\mathrm{BB} / \mathrm{U}<$ usia median $\mathrm{TB} / \mathrm{U}<$ usia kronologis maka dapat dipastikan anak mengalami stunting(2).

Pada tahun 2005-2017, rata-rata prevalensi stunting di Indonesia adalah $36,4 \%{ }^{(3)}$ Di Jawa Timur, persentase balita sangat pendek dan pendek usia 0 23 bulan di Indonesia pada tahun 2018 yaitu $15,2 \%$ dan $18,4 \%{ }^{(3)}$. Berdasarkan rekap data Dinas Kesehatan Kabupaten Malang bulan Februari 2019 Kecamatan Pujon menjadi kecamatan dengan tingkat anak stunting tertinggi di Kabupaten Malang yaitu 311 anak sangat pendek dan 905 anak pendek. Desa Madiredo sendiri merupakan salah satu desa lokus stunting di Kecamatan Pujon dengan 37 anak sangat pendek dan 131 anak pendek ${ }^{(4)}$.

Menurut WHO, stunting dapat menyebabkan gangguan perkembangan motorik halus, motorik kasar, bahasa dan personal sosial(5). Perkembangan motorik halus merupakan aspek perkembangan yang meliputi gerakan tubuh yang melibatkan bagian tubuh tertentu saja dan dijalankan oleh otot-otot kecil. Perkembangan motorik kasar berhubungan dengan pergerakan dan sikap tubuh yang dilakukan oleh otototot besar. Perkembangan bahasa adalah kemampuan anak untuk memberikan respon terhadap suara, mengikuti perintah dan berbicara sopan. Perkembangan personal sosial 
berhubungan dengan perilaku anak dalam menyesuaikan diri dengan aturan masyarakat dan lingkungan.

Perkembangan anak balita dapat diketahui dengan melakukan tes perkembangan. Terdapat beberapa alat untuk tes perkembangan anak balita, salah satunya yaitu Denver Development Screening Test II (Denver II). Tes ini mudah dan cepat (dapat dilakukan sekitar 15-20 menit), dapat diandalkan dan menunjukkan validitas yang tinggi. Denver II digunakan untuk menilai perkembangan anak balita dari empat kategori, yaitu motorik halus, motorik kasar, bahasa dan personal sosial(6).

Penelitian yang dilakukan oleh Hanani dan Syauqi (2016) menunjukkan bahwa hasil tes perkembangan kategori mencurigakan pada anak dengan status gizi stunting memiliki frekuensi yang lebih tinggi dibandingkan dengan anak dengan status gizi non stunting ${ }^{(7)}$. Hasil tes perkembangan pada anak stunting yang masuk pada kategori mencurigakan secara berturut-turut dari yang tertinggi meliputi perkembangan personal sosial, bahasa, motorik kasar, dan motorik halus.

Tingginya angka stunting dan kurang optimalnya perkembangan anak dapat menimbulkan dampak negatif bagi masa depan anak dan dapat menghambat pertumbuhan ekonomi dan kemajuan bangsa Indonesia. Oleh karena itu, untuk mengetahui pengaruh stunting terhadap perkembangan motorik halus, motorik kasar, bahasa dan personal sosial anak balita di Desa Madiredo Kecamatan Pujon perlu dilakukan penelitian lebih lanjut.

\section{METODE PENELITIAN}

Penelitian ini menggunakan desai penelitian cross sectional. Populasi penelitian ini adalah anak balita usia 2-5 tahun di Desa Madiredo Kecamatan Pujon Kabupaten Malang pada Bulan Desember 2019 sampai Januari 2020 sejumlah 449 anak. Teknik purposive sampling digunakan dalam pengambilan subjek. Data yang dikumpulkan menggunakan lembar karakteristik responden, aplikasi mudah menghitung pada android, tabel $z$-score, alat ukur (mikrotois dan timbangan berat badan digital) dan lembar Denver II.

Analisis penelitian menggunakan Uji Fisher's Exact dengan kepercayaan $\alpha<0,05$ yang kemudian data yang diperoleh akan diolah menggunakan SPSS for Windows versi 25.0. Komisi Etik Penelitian Kesehatan Fakultas Kedokteran Universitas Brawijaya telah memberikan persetujuan untuk dilakukannya penelitian ini, yaitu dengan nomor 16/EC/KEPK-S1-KB/02/2020. 
HASIL PENELITIAN

Tabel 1. Distribusi karakteristik data dasar penelitian

\begin{tabular}{|c|c|c|}
\hline Karakteristik & $\mathbf{F}$ & $\%$ \\
\hline \multicolumn{3}{|l|}{ Jenis Kelamin } \\
\hline Perempuan & 19 & 41,3 \\
\hline Laki-laki & 27 & 58,7 \\
\hline Total & 46 & 100,0 \\
\hline \multicolumn{3}{|l|}{ Usia } \\
\hline 5 & 1 & 2,2 \\
\hline 4 & 16 & 34,8 \\
\hline 3 & 15 & 32,6 \\
\hline 2 & 14 & 30,4 \\
\hline Total & 46 & 100,0 \\
\hline \multicolumn{3}{|l|}{ ASI Eksklusif } \\
\hline Tidak & 24 & 52,2 \\
\hline Iya & 22 & 47,8 \\
\hline Total & 46 & 100,0 \\
\hline \multicolumn{3}{|l|}{ Pendidikan Ibu } \\
\hline Rendah (SD/MI \& SMP/MTs) & 34 & 73,9 \\
\hline Menengah (SMA/SMK/MA) & 11 & 23,9 \\
\hline Tinggi (Diploma, S1, S2 \& S3) & 1 & 2,2 \\
\hline Total & 46 & 100,0 \\
\hline \multicolumn{3}{|l|}{ Pekerjaan Ibu } \\
\hline Tidak Bekerja & 45 & 97,8 \\
\hline Bekerja & 1 & 2,2 \\
\hline Total & 46 & 100,0 \\
\hline \multicolumn{3}{|l|}{ Pendidikan Ayah } \\
\hline Rendah & 39 & 84,8 \\
\hline Menengah & 5 & 10,9 \\
\hline Tinggi & 2 & 4,3 \\
\hline Total & 46 & 100,0 \\
\hline \multicolumn{3}{|l|}{ Pekerjaan Ayah } \\
\hline Tidak Bekerja & 1 & 2,2 \\
\hline Bekerja & 45 & 97,8 \\
\hline Total & 46 & 100,0 \\
\hline \multicolumn{3}{|c|}{ Pendapatan Keluarga Tiap Bulan } \\
\hline Rendah $(<1.500 .000)$ & 29 & 63,0 \\
\hline Sedang (1.500.000-2.500.000) & 13 & 28,3 \\
\hline Tinggi $(>2.500 .000)$ & 4 & 8,7 \\
\hline Total & 46 & 100,0 \\
\hline
\end{tabular}

Berdasarkan tabel 1 , dari 46 responden yang diteliti persentase responden laki-laki lebih banyak berpartisipasi dalam mengikuti tes pertumbuhan dan perkembangan $(58,7 \%)$. Usia anak yang paling banyak diteliti yaitu usia 4 tahun sejumlah 16 anak (34,8\%). Responden yang tidak mendapatkan ASI eksklusif lebih dominan, yaitu berjumlah 24 responden $(52,2 \%)$.

Pendidikan ibu didominasi pendidikan rendah yaitu sebanyak 34 orang $(73,9 \%)$. Hampir semua ibu menjadi ibu rumah tangga (tidak bekerja) sebanyak 45 orang $(97,8 \%)$. Pendidikan ayah juga didominasi pendidikan rendah sebanyak 39 orang $(84,8 \%)$. Hampir semua ayah bekerja yaitu sebanyak 45 orang $(97,8 \%)$ dan hanya 1 orang yang tidak bekerja karena sudah meninggal $(2,2 \%)$. Sebagian besar pendapatan keluarga tiap bulan masih dalam tingkat pendapatan rendah $(<1.500 .000)$ yaitu sebanyak 29 keluarga $(63,0 \%)$.

\section{Tabel 2. Pengaruh stunting terhadap} perkembangan anak balita

\begin{tabular}{|c|c|c|c|c|}
\hline \multirow[t]{2}{*}{ Status } & \multicolumn{2}{|c|}{ Motorik Halus } & \multirow{2}{*}{$\begin{array}{l}\text { Total } \\
\text { F (\%) }\end{array}$} & \multirow{2}{*}{$\begin{array}{c}P \\
\text { value }\end{array}$} \\
\hline & Suspect & Normal & & \\
\hline Stunting & $\begin{array}{c}3 \\
(13,0 \%)\end{array}$ & $\begin{array}{c}20 \\
(87,0 \%)\end{array}$ & $\begin{array}{c}23 \\
(50 \%)\end{array}$ & 0,233 \\
\hline Non & 0 & 23 & 23 & \\
\hline Stunting & $(0,0 \%)$ & $(50 \%)$ & $(50 \%)$ & \\
\hline \multirow[t]{3}{*}{ Total } & $\begin{array}{c}3 \\
(6,5 \%)\end{array}$ & $\begin{array}{c}43 \\
(93,5 \%)\end{array}$ & $\begin{array}{c}46 \\
(100 \%)\end{array}$ & \\
\hline & \multicolumn{2}{|c|}{ Motorik Kasar } & Total & \\
\hline & Suspect & Normal & $\mathbf{F}(\%)$ & \\
\hline Stunting & $\begin{array}{c}4 \\
(17,4 \%)\end{array}$ & $\begin{array}{c}19 \\
(82,6 \%)\end{array}$ & $\begin{array}{c}23 \\
(50 \%)\end{array}$ & 0,109 \\
\hline Non & 0 & 23 & 23 & \\
\hline Stunting & $(0,0 \%)$ & $(50 \%)$ & $(50 \%)$ & \\
\hline \multirow[t]{3}{*}{ Total } & $\begin{array}{c}4 \\
(8,7 \%) \\
\end{array}$ & $\begin{array}{c}42 \\
(91,3 \%)\end{array}$ & $\begin{array}{c}46 \\
(100 \%) \\
\end{array}$ & \\
\hline & \multicolumn{2}{|c|}{ Bahasa } & Total & \\
\hline & Suspect & Normal & $\mathbf{F}(\%)$ & \\
\hline Stunting & $\begin{array}{c}6 \\
(26,1 \%)\end{array}$ & $\begin{array}{c}17 \\
(73,9 \%)\end{array}$ & $\begin{array}{c}23 \\
(50 \%)\end{array}$ & 0,022 \\
\hline Non & 0 & 23 & 23 & \\
\hline Stunting & $(0,0 \%)$ & $(50 \%)$ & $(50 \%)$ & \\
\hline \multirow[t]{3}{*}{ Total } & $\begin{array}{c}6 \\
(13,0 \%)\end{array}$ & $\begin{array}{c}40 \\
(87,0 \%)\end{array}$ & $\begin{array}{c}46 \\
(100 \%) \\
\end{array}$ & \\
\hline & \multicolumn{2}{|c|}{ Personal Sosial } & Total & \\
\hline & Suspect & Normal & $F(\%)$ & \\
\hline Stunting & $\begin{array}{c}8 \\
(34,8 \%)\end{array}$ & $\begin{array}{c}15 \\
(65,2 \%)\end{array}$ & $\begin{array}{c}23 \\
(50 \%)\end{array}$ & 0,004 \\
\hline $\begin{array}{l}\text { Non } \\
\text { Stunting }\end{array}$ & $\begin{array}{c}0 \\
(0,0 \%)\end{array}$ & $\begin{array}{c}23 \\
(50 \%)\end{array}$ & $\begin{array}{c}23 \\
(50 \%)\end{array}$ & \\
\hline Total & $\begin{array}{c}8 \\
(17,4 \%)\end{array}$ & $\begin{array}{c}38 \\
(82,6 \%)\end{array}$ & $\begin{array}{c}46 \\
(100 \%)\end{array}$ & \\
\hline
\end{tabular}

Tabel 2 menunjukkan bahwa berdasarkan uji Fisher's Exact dengan menggunakan program SPSS versi 25.0 menunjukkan hasil perkembangan motorik halus dan motorik kasar memiliki nilai $P$ Value $>0,05$, dapat disimpulkan $\mathrm{H}_{0}$ diterima sehingga menunjukkan bahwa stunting tidak berpengaruh signifikan terhadap perkembangan motorik halus dan motorik kasar anak balita usia 2-5 tahun.

Hasil perkembangan bahasa dan personal sosial memiliki nilai $P$ Value $<0,05$, dapat disimpulkan $\mathrm{H}_{0}$ ditolak sehingga menunjukkan bahwa stunting berpengaruh signifikan terhadap perkembangan bahasa dan 
personal sosial anak balita usia 2-5 tahun.

\section{PEMBAHASAN}

\section{Pengaruh Stunting terhadap Perkembangan Motorik Halus}

Berdasarkan hasil uji Fisher's Exact diperoleh nilai $\mathrm{p}=0,233$, hal ini menunjukkan bahwa stunting tidak berpengaruh signifikan terhadap perkembangan motorik halus pada anak balita usia 2-5 tahun. Hasil penelitian ini tidak sejalan dengan penelitian di Afrika Selatan pada anak usia 2 tahun, hasil analisis multivariat menunjukkan bahwa anak stunting mendapatkan lebih banyak hasil buruk dalam tes perkembangan motorik halus ${ }^{(8)}$. Selain itu, penelitian yang dilakukan di Padang juga tidak sejalan dengan penelitian ini, dimana dalam penelitiannya menyatakan bahwa anak balita dengan status gizi stunting lebih memiliki risiko keterlambatan pada perkembangan motorik halus, yaitu $25 \%$ anak mendapatkan hasil tes perkembangan motorik halus suspect(7). Hal ini dapat disebabkan karena keterlambatan perkembangan motorik halus tidak hanya dipengaruhi oleh kondisi status gizi stunting saja.

Perkembangan motorik halus juga dapat dipengaruhi oleh faktor internal dan faktor eksternal. Faktor internal yang dapat memengaruhi yaitu seperti potensi anak dan semangat belajar. Faktor eksternal yang dapat memengaruhi yaitu pengalaman dengan teman sebaya dan lingkungan. Menurut penelitian yang dilakukan di Kabupaten Boalemo pada anak usia 5-6 tahun, lingkungan merupakan faktor paling dominan yang dapat berpengaruh pada perkembangan motorik halus ${ }^{(9)}$.

Lingkungan yang dimaksud adalah lingkungan yang dapat menguntungkan kematangan fungsi-fungsi organ maupun psikis. Kemampuan motorik halus anak didasarkan pada pengaruh lingkungan sekitar anak (10). Anak akan belajar dari lingkungan yang memperlakukannya, baik di lingkungan keluarga maupun sekitar. Terutama pada lingkungan keluarga dengan orang tua yang memiliki perhatian khusus untuk melatih kemampuan motorik halus anak, maka perkembangan motorik anak dapat terasah dengan baik. Seperti pada penelitian ini, ibu dari 20 anak balita stunting yang mendapatkan hasil tes perkembangan motorik halus normal tidak bekerja atau menjadi ibu rumah tangga (IRT). lbu rumah tangga tentunya memiliki waktu lebih banyak di rumah untuk berinteraksi dengan anak. Sehingga, ibu dapat memantau dan menstimulasi perkembangan motorik halus seperti mengajari anak untuk mencorat-coret dan menggambar bentuk-bentuk dasar.

Garis umur yang dilalui anak pada saat pelaksanaan Denver II, khususnya pada kategori motorik halus kebanyakan terpotong pada tes menggambar hal-hal dasar (garis vertikal, lingkaran, kotak, bagian tubuh manusia, dan lain sebagainya), menyusun menara kubus dan menggoyangkan ibu jari. Pada saat proses penelitian, ibu mendampingi anak saat dilakukan tes dan kebanyakan ibu menunjukkan reaksi suportif seperti saat anak tidak percaya diri untuk menggambar sesuatu maka ibu akan mengingatkan seperti apa biasanya mereka melakukan hal tersebut. Tentunya hal tersebut menggambarkan bahwa selama ini ibu memberikan stimulasi perkembangan motorik halus di rumah. Selain itu, ibu juga menyemangati anak dalam pelaksanaan tes. Sehingga, anak yang awalnya mungkin malu-malu dapat menjadi lebih percaya diri untuk menunjukkan kemampuan motorik halusnya. 
Penelitian di Kota Surakarta pada anak berusia 1-3 tahun searah dengan hasil penelitian ini, karena menunjukkan hasil tidak ada perbedaan perkembangan motorik halus antara anak stunted dengan tidak stunted karena mendapatkan hasil yang kontras bahwa kelompok anak stunted secara marginal mempunyai rata-rata skor perkembangan motorik halus yang lebih tinggi dibandingkan dengan anak tidak stunted ${ }^{(11)}$.

\section{Pengaruh Stunting terhadap Perkembangan Motorik Kasar}

Setelah dilakukan uji Fisher's Exact didapatkan hasil bahwa stunting tidak berpengaruh signifikan terhadap perkembangan motorik kasar pada anak balita usia 2-5 tahun, karena diperoleh nilai $p=0,109$. Penelitian ini tidak sejalan dengan penelitian sebelumnya yang dilakukan di Bangladesh pada anak usia 6-24 bulan, dimana dalam penelitiannya menyatakan bahwa anak dengan status gizi stunting lebih memiliki risiko keterlambatan pada perkembangan motorik kasar $(p<0,001)^{(12)}$.

Penelitian ini menguatkan hasil penelitian sebelumnya yang dilakukan di Surakarta pada anak usia 1-3 tahun yang menunjukkan hasil tidak ada perbedaan perkembangan motorik kasar antara anak stunted dengan tidak stunted karena rata-rata skor perkembangan motorik kasar anak stunted hampir sama dengan anak tidak stunted ${ }^{(11)}$.

Hal ini dapat terjadi karena perkembangan motorik kasar dapat dipengaruhi faktor selain stunting, yaitu kualitas interaksi dengan orang tua. Dalam hal ini, tentu saja peran orang tua khususnya ibu sangat penting karena merupakan orang terdekat yang berinteraksi secara langsung dengan anak. Pada penelitian ini didapatkan hampir semua ibu tidak bekerja atau menjadi ibu rumah tangga $(97,8 \%)$. Sehingga ibu memiliki waktu yang lebih banyak untuk memantau secara langsung proses tumbuh kembang anak dengan memberikan latihan dan motivasi. Karena ibu memiliki peran yang sangat penting pada tumbuh kembang anak, khususnya dalam hal ini yaitu perkembangan motorik kasar.

Lingkungan yang meliputi latihan, motivasi dan pengalaman juga dapat menjadi faktor yang dapat memengaruhi perkembangan motorik kasar(13). Apabila orang tua memberikan latihan dan motivasi kepada anak untuk berkembang, maka anak akan memiliki pengalaman yang baik untuk mengembangkan potensi khususnya perkembangan motorik kasar. Orang tua diharapkan tidak membatasi ruang gerak anak agar anak dapat mengeksplorasi kemampuan yang ada dalam dirinya, namun tetap mengawasi dengan seksama setiap progres perkembangan yang dilakukan anak.

Tidak hanya pada lingkup keluarga, lingkup teman sebaya pun turut memberikan dampak pada perkembangan motorik kasar anak. Lingkungan bermain yang suportif dapat memberikan dampak positif pada anak. Di lokasi penelitian, umunya anak-anak aktif bermain bersama teman-temannya dengan beraktivitas di luar rumah. Halhal yang biasa mereka lakukan yaitu seperti bermain lari-larian, bermain bola, bermain loncat jauh, permainan dengan menggunakan kekuatan salah satu kaki dan permainan lainnya. Garis umur yang dilalui anak pada saat pelaksanaan Denver II, khususnya pada kategori motorik kasar kebanyakan terpotong pada tes lari, melompat, menendang bola, loncat jauh, berdiri dengan satu kaki dan lain sebagainya. Sehingga, pada saat dilakukan tes perkembangan motorik kasar, hanya 
sebagian kecil saja yang memiliki hasil tes suspect $(8,7 \%)$.

\section{Pengaruh Stunting terhadap Perkembangan Bahasa}

Berlandaskan dari hasil uji statistic menggunakan Fisher's Exact diperoleh nilai $\mathrm{p}=0,022$, hal ini menunjukkan bahwa stunting berpengaruh signifikan terhadap perkembangan bahasa pada anak balita usia 2-5 tahun. Stunting merupakan salah satu masalah kesehatan yang dapat terjadi pada anak balita. Menurut WHO, stunting dapat menyebabkan gangguan perkembangan bahasa pada anak ${ }^{(5)}$. Hal tersebut dikarenakan stunting merupakan manifestasi dari kekurangan asupan gizi dalam jangka waktu yang lama. Sehingga perkembangan sel-sel otak dapat terhambat. Hal ini tentu saja akan menghambat proses pertumbuhan akson dan dendrit, formasi sinapsis dan proses mielinisasi, yang sangat memengaruhi percepatan impuls syaraf dari satu sel otak ke sel otak yang lain. Zat gizi yang dapat memengaruhi proses perkembangan otak yaitu meliputi protein, energi, asam lemak esensial serta zat gizi mikro seperti zink, zat besi, vitamin B dan Yodium ${ }^{(14)}$. Bagian otak yang mungkin dapat terganggu pertumbuhan dan perkembangannya yaitu otak bagian hemisfer kiri pada area broca dan area wernicke yang mengatur kemampuan bicara dan bahasa ${ }^{(15)}$.

Selain itu, pada penelitian ini seluruh orang tua anak balita yang mengalami keterlambatan perkembangan bahasa memiliki riwayat pendidikan rendah yaitu rata-rata hanya menempuh pendidikan SD dan SMP. Sesuai dengan hasil penelitian di Nusa Tenggara Timur, pendidikan memiliki hubungan yang signifikan dengan kejadian stunting(16). Pada penelitian yang dilakukan oleh Pancsofar dan Vemon-Feagans dalam Gunawan (2011), menyatakan bahwa tingkat pendidikan orang tua mempunyai pengaruh yang bermakna pada kemampuan bicara dan bahasa anak ${ }^{(17)}$. Hal tersebut karena dapat memberikan dampak pada pola bahasa dalam keluarga. Orang tua dengan pendidikan yang rendah cenderung memiliki pengetahuan yang kurang baik dan berdampak pada rendahnya kualitas stimulasi bahasa yang diberikan pada anak. Sehingga terdapat keterkaitan antara rendahnya tingkat pendidikan orang tua, kejadian stunting dan terhambatnya perkembangan bahasa pada anak.

Namun, tidak hanya rendahnya pendidikan orang tua saja yang terkait dengan stunting dan perkembangan bahasa anak balita. Perkembangan bahasa anak balita dapat berkembang sesuai usianya apabila orang tua sering memberikan stimulasi pada anak. Pada saat penelitian, khususnya pada anak stunting yang mendapatkan hasil perkembangan bahas suspect, rata-rata ibu jarang memberikan stimulasi. Contohnya seperti saat tes menyebutkan warna, beberapa ibu mengatakan anaknya belum diajari untuk mengenal warna. Karena ibu terkadang terlalu sibuk mengerjakan pekerjaan rumah dan membiarkan anak-anaknya bermain di luar rumah tanpa pengawasan ibu.

Penelitian ini sependapat dengan penelitian yang dilakukan pada anak berusia 6-24 bulan di Bangladesh, yaitu adanya hubungan yang signifikan antara stunting dengan perkembangan bahasa $(p<0,001)^{(12)}$.

\section{Pengaruh Stunting terhadap Perkembangan Personal Sosial}


Penelitian ini menunjukkan hasil bahwa stunting berpengaruh signifikan terhadap perkembangan personal sosial pada anak balita usia 2-5 tahun karena pada uji Fisher's Exact diperoleh nilai $\mathrm{p}=0,004$. Badan kesehatan dunia WHO pada tahun 2013 menyatakan bahwa anak balita dengan status gizi stunting dapat menyebabkan gangguan pada perkembangan personal sosial ${ }^{(5)}$. Status gizi stunting dapat disebabkan oleh faktor langsung seperti akumulasi dari tidak tercukupinya kebutuhan nutrisi anak balita. Sehingga kebutuhan gizi yang diperoleh anak tidak sesuai atau bahkan kekurangan. Tidak terpenuhinya kebutuhan gizi anak yang sesuai juga dapat menyebabkan terhambatnya pertumbuhan dan perkembangan.

Anak yang mengalami kekurangan makanan bergizi cenderung menjadi lemah dan tidak aktif, sehingga terjadi penurunan interaksi dengan lingkungannya dan menyebabkan adanya perkembangan yang buruk, ditandai dengan aktivitas yang menurun, lebih rewel dan tidak merasa bahagia, serta tidak begitu menunjukkan rasa ingin tahu (naluri eksplorasi). Tentu saja hal-hal tersebut dapat menghambat anak untuk mengembangkan potensinya untuk beradaptasi dengan lingkungan sosialnya. Hal ini juga sesuai dengan penelitian pada anak usia 4-5 tahun di Kabupaten Jember, bahwa orang tua yang memenuhi kebutuhan gizi seimbang anak, maka berpeluang 4,12 kali untuk memiliki anak dengan perkembangan personal sosial yang baik $^{(18)}$.

Pada penelitian ini hampir semua orang tua anak balita stunting yang mengalami keterlambatan perkembangan personal sosial memiliki pendapatan keluarga per bulan yang rendah, yaitu rata-rata hanya Rp1.000.000,- per bulannya. Hal ini seperti penelitian di Madiun kepada anak balita usia 1-5 tahun yang mengutarakan bahwa keluarga yang berpendapatan tinggi mempunyai peluang 0,22 kali mendapati perkembangan personal sosial normal dibandingkan keluarga berpendapatan rendah ${ }^{(19)}$.

Keluarga, khususnya orang tua yang merupakan lingkungan sosial pertama yang berinteraksi dengan anak memegang peranan yang sangat serius dalam proses perkembangan sosial anak. Oleh karena itu, perlu diperhatikan pengetahuan orang tua, pola asuh orang tua, tingkat pendapatan keluarga, serta pemberian nutrisi yang diberikan pada anak ${ }^{(20)}$. Semua faktor tersebut saling berkaitan satu sama lain.

Pada saat dilakukannya penelitian, beberapa poin yang paling sering mendapatkan hasil gagal (failed) pada kategori perkembangan personal sosial anak yaitu pada poin memakai baju atau kemeja sendiri. Beberapa ibu mengatakan bahwa apabila anaknya tidak dapat melakukan secara mandiri karena selama ini kebanyakan ibu merupakan ibu rumah tangga. Sehingga, aktifitas mulai dari memandikan anak sampai memakaikan baju kepada anak pun juga dilakukan oleh ibu. Sehingga anak kurang mendapatkan kesempatan untuk belajar memakai pakaian sendiri.

Penelitian ini mendukung penelitian sebelumnya di Semarang pada anak usia 24-59 bulan yang menunjukkan bahwa terdapat hubungan yang signifikan antara stunting dengan perkembangan personal sosial anak, yaitu $87,5 \%$ anak mendapatkan hasil tes perkembangan personal sosial suspect ${ }^{(7)}$. Namun, penelitian pada anak usia 2 tahun yang lahir di daerah perkotaan Afrika Selatan menunjukkan hasil yang berbeda dengan penelitian ini yaitu stunting tidak berpengaruh secara 
signifikan terhadap perkembangan psikososial anak dengan menggunakan Vineland Social Maturity Scale (VSMS) sebagai instrument pengukurannya ${ }^{(8)}$.

\section{KESIMPULAN}

1. Hasil tes perkembangan kategori suspect pada penelitian ini seluruhnya terjadi pada anak balita dengan status gizi stunting.

2. Stunting tidak memengaruhi perkembangan motorik halus dan motorik kasar dimana nilai $p>0,05$.

3. Stunting memengaruhi perkembangan bahasa dan personal sosial dengan nilai $p<0,05$.

4. Hasil tes perkembangan kategori suspect penelitian ini secara berturutturut adalah perkembangan motorik halus $(13,0 \%)$, perkembangan motorik kasar (17,4\%), perkembangan bahasa $(26,1 \%)$ dan perkembangan personal sosial $(34,8 \%)$.

\section{DAFTAR PUSTAKA}

1. WHO. 2010. Nutrition Landscape Information System (NLIS) Country Profile Indicators: Interpretation Guide. Switzerland: WHO Press.

2. IDI \& IDAI. 2019. How To Prevent Stunting: Detection And Manage Growth Deceleration Workshop. Makalah disajikan dalam Workshop $3^{\text {rd }}$ Indonesian Pediatric Nutrition And Metabolic Update (NUTRIMET), Nutrition \& Metabolic Disease Working Group - Indonesian Pediatric Society, Solo, 27 April 2019.

3. Kemenkes RI. 2018. Riset Kesehatan Dasar. Jakarta: Badan Penelitian dan Pengembangan Kementerian Kesehatan RI.

4. Kemenkes RI. 2018. Riset Kesehatan Dasar. Jakarta: Badan Penelitian dan Pengembangan Kesehatan Kementerian Kesehatan RI.

5. WHO. 2013. Childhood Stunting: Challenges and opportunities. Available from:

https://apps.who.int/iris/bitstream/handl e/10665/107026/WHO NMH NHD G RS 14.1 eng.pdf;jsessionid=89D07C3 A25CODBE9A1E8405BBF5DFB6F?se quence $=1$

6. Sembiring, JB. 2019. Asuhan Neonatus, bayi, Balita, Anak Pra Sekolah. Yogyakarta: Deepublish.

7. Hanani, Ruth dan Syauqy, Ahmad. 2016. Perbedaan Perkembangan Motorik Kasar, Motorik Halus, Bahasan dan Personal Sosial pada Anak Stunting dan Non Stunting. Journal of Nutrition College. 5(4): 412-418.

8. Casale, D., dkk. 2014. The Association Between Stunting and Psychosocial Development among Preschool Children: A Study Using The South African Birth to Twenty Cohort Data. Child: Care, Health, and Development. 40(6):900-910.

9. Dunggio, N. 2018. Faktor-Faktor yang Memengaruhi Perkembangan Motorik Halus Anak Usia 5-6 Tahun di TK Madani Desa Bubaa Kecamatan Paguyaman Pantai Kabupaten Boalemo. Tugas Akhir. Jurusan Pendidikan Guru Pendidikan Anak Usia Dini Fakultas IImu Pendidikan Universitas Negeri Gorontalo, Gorontalo.

10. Sanggila, Selvi. 2016. Faktor-Faktor yang Memengaruhi Kemampuan Motorik Halus Anak dengan Mewarnai Teknik Gradasi Kelompok B di TK Alam III Kecamatan Tilamuta Kabupaten Boalemo. Tugas Akhir. Fakultas IImu Pendidikan Universitas Negeri Gorontalo, Gorontalo.

11. Wani, YA. 2010. Perkembangan Motorik Kasar dan Motorik Halus pada Anak-Anak Stunted Usia 1-3 Tahun di Permukiman Kumuh Kota Surakarta. Tugas Akhir. S2 Fakultas IImu Kesehatan Masyarakat Universitas Gadjah Mada, Yogyakarta.

12. Nahar, B., dkk. 2019. Early Childhood Development and Stunting: Findinggs from The MAL-ED Birth Cohort Study in Bangladesh. WILEY Maternal \& Child Nutrition Journal. 16(1):1-12. 
13. Kamtini. 2014. Motorik Kasar Anak Usia Dini. Medan: Media Persada.

14. Prado, EL dan Dewey,KG. 2014. Nutrition and Brain Development in Early Life. Nutrition Reviews. 72(4):267-284.

15. Antonius, P. 2018. Psikolinguistik: Memahami Aspek Mental dan Neurologis Berbahasa. Jakarta: PT Gramedia.

16. Picauly, I \& Toy, S. M. 2013. Analisis Determinan dan Pengaruh Stunting terhadap Prestasi Belajar Anak Sekolah di Kupang dan Sumba Timur, NTT. Jurnal Gizi Dan Pangan. 8(1): 5562.

17. Gunawan, G. dkk. 2011. Gambaran Perkembangan Bicara dan Bahasa Anak Usia 0-3 Tahun. Jurnal Sari Pediatri. 13(1):21-25.
18. Trisnawati, E. dkk. 2013. Hubungan Pemenuhan Gizi Seimbang dengan Perkembangan Personal Sosial Anak Usia Prasekolah di Taman KanakKanak Dharmawanita Kecamatan Arjasa Kabupaten Jember. Tugas Akhir. Fakultas IImu Keperawatan Universitas Jember, Jember.

19. Firdaus, ND. 2018. Hubungan Tingkat Pendapatan Keluarga, Tingkat Pengetahuan lbu tentang Stimulasi perkembangan Anak dan Tingkat Pendidikan lbu dengan Perkembangan Sosial Anak Balita di Kota Madiun. Tugas Akhir. Fakultas Kedokteran Universitas Muhammadiyah Surakarta, Surakarta.

20. Supariasa, IDN. dkk. 2012. Penilaian Status Gizi. Jakarta: EGC. 